\title{
ANALISIS SISTEM DAN PROSEDUR PENERIMAAN RETRIBUSI DAERAH DI KABUPATEN MINAHASA SELATAN SESUAI DENGAN PERMENDAGRI NOMOR 13 TAHUN 2006 TENTANG PEDOMAN PENGELOLAAN KEUANGAN DAERAH
}

\author{
Watupongoh Risky Aldy ${ }^{1}$, Jullie J Sondakh ${ }^{2}$, Lidia Mawikere ${ }^{3}$ \\ ${ }^{123}$ Jurusan Akuntansi, Fakultas Ekonomi dan Bisnis, Universitas Sam Ratulangi Manado, Jl. Kampus Bahu, \\ Manado 95115, Indonesia \\ Email : aldy.wt9494@gmail.com
}

\begin{abstract}
Regional Levy Income is a part of Regional Original Income that can support regional revenues in accordance with regional regulations (Perda) issued by local governments. The purpose of this study was to determine the system and procedures for receiving regional levies in South Minahasa regency in accordance with Permendagri Number 13 of 2006. The analytical method used was descriptive analysis, while analysis of systems and procedures was carried out by comparing concepts, theories and regulations in the implementation of the system and procedures for receiving regional levies specifically with the provisions of Permendagri Number 13 of 2006. The results of the study obtained that in general the System and Procedure for Regional Retribution in South Minahasa is in accordance with PERMENDAGRI Number 13 of 2006 concerning regional financial management guidelines. Keywords : system; procedure; receiving; regional retribution; financial management
\end{abstract}

\section{PENDAHULUAN}

Kemajuan suatu bangsa sangat dipengaruhi oleh peran dan kerja sektor publik (Mahmudi, 2013 : 1). Bahkan bisa dikatakan tidak mungkin ada negara tanpa kehadiran sektor publik. Sektor publik memiliki peran yang tidak kecil dalam suatu negara yang berdampak pada sektor yang lain yaitu sektor swasta maupun sektor sosial. Oleh karena itu untuk kemajuan suatu bangsa, maka sektor publik tidak boleh diabaikan. Pemerintah sebagai penyelenggara kekuasaan negara harus bisa menyediakan public goods and service untuk kesejahteraan masyarakat pada umunya. Pemerintah sebagai organisasi sektor publik harus bertanggungjawab untuk meningkatkan kesejahteraan masyarakat, menjunjung tinggi keinginan rakyat, melaksanakan pembangunan berkelanjutan dan berkeadilan sosial, menjalankan aspek - aspek fungsional dari pemerintah secara efisien dan efektif sehingga bisa terwujud Pemerintah yang baik dan bersih. Demikian pun dengan Negara Kesatuan Republik Indonesia yang menganut negara Pancasila, yang menjadikan sektor publik sangat penting dalam pengelolaan pemerintahan negara.

Penyelenggaraan pengelolaan pemerintahan Negara Kesatuan Republik Indonesia terdapat peraturan dan kebijakan yang dibuat dengan tujuan menopang terciptanya penyelenggaraan negara yang baik yang memungkinkan terjadinya pemerintahan yang bersih dan jauh dari berbagai masalah - masalah yang pada akhinya akan membawa kejatuhan pada negara, tetapi melainkan bertujuan membawa kesejahteraan pada masyarakat yang ada lewat pemanfaatan sumberdaya - sumberdaya yang dimiliki dan dikelola dengan baik yang ditopang dengan administrasi yang benar.Pengelolaan pemerintahan negara juga tidak pernah lepas dari penganggaran yang menjadi instrumen perencanaan dan pengendalian manajemen dalam pemerintah. Dalam penganggaran pemerintah, selalu berkaitan erat dengan Anggaran Pendapatan Dan Belanja Negara (APBN) yang disusun atau dibuat oleh eksekutif dan 
legislatif yang bertujuan untuk memakmurkan rakyatnya. Adapun APBN terdiri atas anggaran pendapatan, anggaran belanja, dan pembiayaan.

Pengelolaan pemerintahan daerah sangat berkaitan erat dengan proses penganggaran seperti yang dilakukan oleh pemerintah pusat. Dalam penganggaran pemerintah daerah selalu juga berkaitan erat dengan Anggaran Pendapatan dan Belanja Daerah (APBD) yang disusun dan dibuat oleh eksekutif dan legislatif daerah yang bertujuan kesejahteraan dan kemakmuran rakyat didaerah. APBD terdiri atas anggaran pendapatan, anggaran belanja, dan pembiayaan. Penerimaan kas daerah/pendapatan daerah menurut Undang-undang Nomor 32 Tahun 2004 dikelompokkan menjadi empat yakni, Pendapatan Asli Daerah (PAD), Dana Perimbangan, Pinjaman Daerah dan Pendapatan Lain-lain yang Sah. Penerimaan pendapatan daerah menurut Peraturan Menteri Dalam Negeri (Permendagri) Nomor 13 Tahun 2006 dapat dilakukan dengan beberapa cara seperti : penerimaan melalui bendahara penerimaan, penerimaan melalui bendahara penerimaan pembantu, dan penerimaan melalui bank, kantor pos dan lain sebagainya. Potensi sumberdaya yang dimiliki oleh daerah berperan penting dalam penerimaan pendapatan daerah, selain itu kebijakan dan regulasi yang dibuat oleh pemerintah daerah juga ikut berperan penting dalam proses penerimaan pendapatan daerah. Kesejahteraan dan kemakmuran rakyat bisa juga dilihat dari potensi dari penerimaan suatu daerah, karena semua pembiayaan daerah untuk kepentingan rakyat akan dapat terealisasi lewat pendapatan daerah. Pendapatan Retribusi Daerah adalah bagian dari Pendapatan Asli Daerah yang dapat menunjang penerimaan daerah sesuai dengan peraturan daerah (Perda) yang dikeluarkan oleh pemerintah daerah. Tujuan hendak dicapai dari penelitian ini adalah untuk mengetahui Sistem dan Prosedur Penerimaan Retribusi Daerah pada Dinas Pendapatan, Pengelolaan Keuangan, dan Aset Daerah Kabupaten Minahasa Selatan sesuai dengan Permendagri No. 13 Tahun 2006 tentang Pedoman Pengelolaan Keuangan Daerah.

\section{TINJAUAN PUSTAKA}

\subsection{Akuntansi}

Menurut Mardiasmo (2018:3) Akuntansi merupakan suatu aktivitas yang memiliki tujuan (purpose activity). Akuntansi digunakan baik pada sektor swasta maupun sektor publik untuk tujuan-tujuan yang berbeda. Sedangkan Pengertian Akuntansi oleh Amerika Institute of Certified Public Accountants (AICPA), akuntansi adalah suatu kegiatan jasa, fungsinya adalah menyediakan data kuantitatif terutama yang mempunyai sifat dari kesatuan usaha ekonomi yang dapat digunakan dalam pengambilan keputusan-keputusan dalam memilih alternatif-alternatif dari suatu keadaan atau dapat dikatakan : Akuntansi adalah suatu proses pencatatan, penggolongan, peringkasan, dan penyajian secara sistematis dari transaksitransaksi keuangan suatu badan usaha, serta penafsiran terhadap hasilnya. (Novi Priyati, 2016:1). Menurut Pasal 1 Peraturan Pemerintah Nomor 71 Tahun 2010 tentang pengertian akuntansi, adalah proses identifikasi, pencatatan, pengukuran, pengklasifikasian, pengikhtisaran transaksi dan kejadian keuangan, penyajian laporan, serta penginterpretasian atas hasilnya.

\subsection{Akuntansi Sektor Publik}

Akuntansi sektor Publik merupakan alat informasi baik bagi pemerintah sebagai manajemen maupun alat informasi bagi publik. Bagi pemerintah, informasi akuntansi digunakan dalam proses pengendalian manajemen mulai dari perencanaan strategik, pembuatan program, penganggaran, evaluasi kinerja, dan pelaporan kinerja. (Mardiasmo, 2018:18). Sedangkan Mursyidi (2009:1) menyatakan: Akuntansi sektor publik melas pada semua entitas yang bertujuan untuk kesejahteraan masyarakat, misalnya yayasan sosial, lembaga swadaya masyarakat (LSM) dan proyek-proyek kerjasama sektor publik dan swasta. 


\subsection{Standar Akuntansi Pemerintah}

(Mahmudi, 2013 : 271) menyatakan Standar akuntansi pemerintah merupakan salah satu aspek penting yang diperlukan untuk meningkatkan kualita tata kelola keuangan Negara dan pelaporan keuangan pemerintahan. Terdapat banyak pihak yang berkepentingan dengan standar akuntansi pemerintahan antara lain : penyajian laporan keuangan, auditor, masyarakat pengguna laporan keuangan, organisasi profesi akuntansi, akademisi, dan pemerintah. Sedangkan Sitorus (2015) menjelaskan bahwa akuntansi pemerintahan adalah sebuah kegiatan jasa dalam rangka menyediakan informasi kuantitatif terutama yang bersifat keuangan dari entitas pemerintah guna pengambilan keputusan ekonomi yang nalar dari pihak - pihak yang berkepentingan atau berbagai alternatif arah tindakan.

\subsection{Sistem Akuntansi Penerimaan Pendapatan Daerah}

Berdasarkan Peraturan Menteri Dalam Negeri Nomor 13 Tahun 2006, Penerimaan Pendapatan Daerah dapat dilakukan dengan 3 (tiga) cara, yaitu melalui :

a. Bendahara Penerimaan;

b. Bendahara Penerimaan Pembantu; dan

c. Bank Pemerintah, Bank Lain, Badan, Lembaga Keuangan, Kantor Pos.

\section{Pelaksana}

Pelaksana sistem akuntansi penerimaan kas adalah sebagai berikut :

1. Tingkat SKPD dilaksanakan oleh PPK - SKPD (Pejabat Penatausahaan Keuangan Satuan Kerja Perangkat Daerah), Bendahara Penerimaan, dan Bendahara Penerimaan Pembantu.

2. Tingkat SKPKD dilaksanakan oleh PPKD (Pejabat Pengelola Keuangan Daerah) Fungsi Akuntansi, Bendahara Penerimaan, dan Bendahara Penerimaan Pembantu.

\section{Dokumen}

Dokumen yang digunakan dalam sistem akuntansi penerimaan kas antara lain:

1. Surat Ketetapan Pajak Daerah (SKPD);

2. Surat Ketetapan Retribusi Daerah;

3. Surat Tanda Setoran (STS);

4. Surat Tanda Bukti Penerimaan (STBP);

5. Nota Kredit;

6. Bukti Transfer;

7. Dokumen lainnya.

\section{Catatan Akuntansi} meliputi :

Buku catatan akuntansi yang digunakan dalam sistem akuntansi penerimaan kas

1. Buku Jurnal Penerimaan Kas;

2. Buku Kas Umum;

3. Buku Rekapitulasi Penerimaan Harian;

4. Buku Besar Kas;

5. Buku Besar Pembantu Penerimaan Kas.

\subsection{Prosedur Akuntansi Penerimaan Kas Daerah}

Menurut (Mahmuudi, 2013 : 218) Prosedur Akuntansi Penerimaan Kas Daerah adalah :

a. Sistem dan Prosedur Penatausahaan Penerimaan Kas di SKPD terdiri atas :

1. Sistem dan Prosedur penatausahaan penerimaan kas dari pajak dan retribusi daerah melalui Bendahara Penerimaan.

2. Sistem dan Prosedur penatausahaan penerimaan kas dari pajak dan retribusi daerah melalui Bendahara Penerimaan Pembantu.

3. Sistem dan Prosedur penatausahaan penerimaan kas dari pajak dan retribusi daerah melalui Badan, Lembaga Keuangan, atau Kantor Pos yang ditunjuk oleh pemerintah daerah. 
b. Sistem dan Prosedur Akuntansi Penerimaan Kas di SKPKD merupakan kelanjutan dari sistem dan prosedur penatausahaan penerimaan kas di SKPD yang kemudian diverifikasi dan dicatat ke dalam buku jurnal penerimaan kas, buku besar dan buku pembantu.

\subsection{Retribusi Daerah}

Menurut Pasal 1 Undang-Undang Nomor 28 Tahun 2009 Tentang Pajak Daerah dan Retribusi Daerah menyatakan retribusi adalah pungutan daerah sebagai pembayaran atas jasa atau pemberian izin tertentu yang khusus disediakan dan/atau diberikan oleh pemerintah daerah untuk kepentingan orang pribadi atau badan.Pasal 1 Undang Undang Nomor 2 Tahun 2009 juga menyatakan Wajib retribusi adalah orang pribadi atau badan yang menurut peraturan perundang-undangan retribusi diwajibkan untuk melakukan pembayaran retribusi, termasuk pemungut atau pemotong retribusi tertentu. Besarnya retribusi yang terutang oleh orang pribadi atau badan yang menggunakan jasa atau perizinan tertentu dihitung dengan cara mengalikan tarif retribusi dengan penggunaan jasa.

\subsection{Sistem dan Prosedur Penerimaan Kas Daerah}

\section{a. Oleh Bendahara Penerimaan}

Permendagri Nomor 13 Tahun 2006 Pasal 187 sampai 189 mengatur tata cara pelaksanaan penerimaan daerah yang dikelola oleh Bendahara Penerimaan. Bendahara Penerimaan wajib menyelenggarakan penatausahaan terhadap seluruh penerimaan dan penyetoran yang menjadi tanggung jawabnya.Secara administratif, Bendahara Penerimaan SKPD bertanggungjawab kepada Pengguna Anggaran atas pengelolaan uang yang menjadi tugasnya. Namun secara fungsional, Bendahara Penerimaan SKPD bertanggungjawab kepada PPKD selaku BUD. Langkah-langkah teknis dalam penerimaan oleh Bendahara Penerimaan adalah sebagai berikut :

1. Pengguna Anggaran menyerahkan Surat Ketetapan Retribusi Daerah (SKRD) kepada Bendahara Penerimaan. Bendahara Penerimaan menggunakan Surat Ketetapan Retribusi Daerah (SKRD) sebagai dokumen sumber untuk melakukan penatausahaan penerimaan.

2. Bendahara Penerimaan memverifikasi penerimaan uang dengan Surat Ketetapan Retribusi Daerah (SKRD) yang bersangkutan.

3. Setelah melakukan verifikasi, Bendahara Penerimaan menerbitkan Surat Tanda Setor dan Surat Tanda Bukti Pembayaran/Bukti Lain yang Sah.

4. Bendahara menyerahkan Surat Tanda Setor kepada Bank dan Tanda Bukti Pembayaran/Bukti Lain yang Sah kepada Wajib Retribusi.

5. BUD menerima Nota Kredit dari Bank atas STS yang diterimanya dari Bendahara Penerimaan.

\section{b. Oleh Bendahara Penerimaan Pembantu}

Permendagri 13/2006 Pasal 190 mengatur tata cara pelaksanaan penerimaan daerah yang dikelola oleh Bendahara Penerimaan Pembantu.Bendahara Penerimaan Pembantu dapat ditunjuk dalam keadaan objek pendapatan tersebar dan atas pertimbangan geografis, wajib pajak/retribusi tidak dapat membayar kewajibannya secara langsung pada badan/lembaga keuangan/kantor pos yang terkait. Langkah-langkah teknis dalam penerimaan oleh Bendahara Penerimaan Pembantu adalah sebagai berikut :

1. Pengguna Anggaran menyerahkan Surat Ketetapan Retribusi Daerah (SKRD) kepada Bendahara Penerimaan Pembantu. Bendahara Penerimaan Pembantu menggunakan Surat Ketetapan Retribusi tersebut sebagai dokumen sumber untuk melakukan penatausahaan penerimaan.

2. Bendahara Penerimaan Pembantu memverifikasi penerimaan uang dengan Surat Ketetapan Retribusi Daerah (SKRD).

3. Setelah melakukan verifikasi, Bendahara Penerimaan Pembantu menerbitkan Surat Tanda Setoran dan Surat Tanda Bukti Pembayaran/Bukti Lain yang sah. STS 
diserahkan kepada Bank, sedangkan Surat Tanda Bukti Pembayaran/Bukti Lain yang sah diserahkan kepada Wajib Retribusi.

4. Surat Ketetapan Retribusi Daerah (SKRD) diserahkan kepada Bendahara Penerimaan. Bendahara penerimaan melakukan verifikasi, evaluasi, dan analisis atas laporan pertanggungjawaban penerimaan.

5. BUD menerima Nota Kredit dari Bank atas STS yang diterimanya dari Bendahara Penerimaan Pembantu.

\section{c. Oleh Bank Pemerintahan yang ditunjuk, Bank Lain, Badan, Lembaga Keuangan,} dan/atau Kantor Pos

Permendagri 13/2006 Pasal 187 mengatur bahwa Penerimaan Daerah dapat disetor ke rekening kas daerah dengan cara disetor langsung ke bank yang ditunjuk. Bank tersebut merupakan bank sehat yang ditunjuk secara resmi dengan keputusan kepala daerah. Penyetoran tersebut juga dapat dilakukan melalui Bank Lain, Badan, Lembaga Keuangan, dan/atau Kantor Pos.Bank/Lembaga Keuangan tersebut mempertanggungjawabkan uang kas yang diterimanya Kepala Daerah melalui BUD.Langkah-langkah teknis dalam penerimaan oleh Bank Pemerintah yang ditunjuk, Bank Lain, Badan, Lembaga Keuangan, dan/atau Kantor Pos adalah sebagai berikut :

1. Pengguna Anggaran menyerahkan Surat Ketetapan Retribusi Daerah (SKRD) kepada Bendahara Penerimaan dan Wajib Retribusi.

2. Kemudian, Kasda menerima uang dari Wajib Retribusi membuat Bukti Setoran dan Nota Kredit. Bukti Setoran diserahkan kepada Wajib Retribusi, sedangkan Nota Kredit diserahkan kepada BUD. Wajib Retribusi menyerahkan Bukti Setoran kepada Bendahara Penerimaan.

3. Bendahara Penerimaan menerima Slip Setoran/Bukti Lain yang Sah dari Wajib Retribusi atau mendapatkan salinannya dari bank, dan akan menggunakannya sebagai dokumen sumber dalam penatausahaan penerimaan bersama - sama dengan Surat Ketetapan Retribusi Daerah (SKRD).

\subsection{Penelitian Terdahulu}

1. Ersita, Elim (2016) dengan judul Analisis Efektivitas Penerimaan Retribusi Daerah Dan Kontribusinya Terhadap Peningkatan Pendapatan Asli Daerah (PAD) Di Provinsi Sulawesi Utara. Tujuan dari Penelitian ini untuk mengetahui bagaimana efektivitas retribusi daerah di provinsi sulawesi utara tahun 20112015 dan bagaimana kontribusi retribusi daerah terhadap pad di provinsi sulawesi utara (sulut) tahun 2011-2015. Hasil penelitian menunjukkan Tingkat efektivitas untuk retribusi daerah selama tahun 20112015 masuk dalam kategori Cukup efektif. Kontribusi retribusi daerah PAD Provinsi SULUT dari tahun 2011-2015 berkontribusi sedang tetapi rasio kontribusinya cenderung naik setiap tahunnya hanya pada tahun 2015 mengalami penurunan.

2. Janis, Sondakh, Sabijono (2015) dengan judul Analisis Sistem dan Prosedur Penerimaan PAD Pada Dinas Pendapatan Pengelolaan Keuangan dan Aset Daerah Kabupaten Sitaro. Tujuan dari penelitian ini untuk mengetahui sistem dan prosedur penerimaan pad pada dinas pendapatan pengelolaan keuangan dan aset daerah kabupaten sitaro. Hasil penelitian menunjukkan bahwa Sistem dan Prosedur Penerimaan PAD yang diterapkan oleh Dinas Pendapatan Pengelolaan Keuangan dan Aset Daerah telah sesuai dengan Permendagri No. 59 Tahun 2007

3. Najoan, Sabijono, Datu(2016) dengan judul Analisis Sistem Pemungutan dan Penyetoran Retribusi Pasar Pada Dinas Perindustrian Perdagangan Koperasi dan Penanaman Modal Kota Kotamobagu. Tujuan dari penelitian ini untuk menganalisis sistem pemungutan dan penyetoran retribusi pasar pada dinas perindustrian perdagangan koperasi dan penanaman modal kota kotamobagu. Hasil penelitian menunjukkan Sistem Pemungutan dan Penyetoran Retribusi Pasar Pada Dinas 
Perindustrian Perdagangan Koperasi dan Penanaman Modal Kota Kotamobagu Telah Memadai.

4. Karamoy (2013) dengan judul Evaluasi Pelaksanaan Sistem dan Prosedur Penerimaan Kas Di Dinas Pendapatan Kota Manado. Tujuan dari penelitian ini untuk mengetahui pelaksanaan sistem dan prosedur penerimaan kas serta mengevaluasi sistem dan prosedur penerimaan kas pada dinas pendapatan di kota manado. Hasil Penelitian menunjukkan Sistem dan Prosedur Penerimaan Kas yang diterapkan oleh Dinas Pendapatan Kota Manado Telah Sesuai dengan Permendagri No. 59 Tahun 2007.

5. Taluke (2013) dengan judul Analisis Kontribusi Pajak dan Retribusi Daerah Pada PAD Kabupaten Halmahera Barat. Tujuan dari penelitian ini Untuk Mengetahui Kontribusi Pajak dan Retribusi Daerah. Hasil Penelitian ini Menunjukkan Pendapatan Asli Daerah Sangat Bergantung Pada Pajak dan Retribusi Daerah.

\section{METODE PENELITIAN}

\subsection{Jenis Penelitian}

Jenis penelitian ini bersifat deskriptif, untuk menjelaskan bagaimana Pelaksanaan Sistem dan Prosedur Penerimaan Retribusi Daerah Di Kabupaten Minahasa Selatan sesuai dengan Permendagri Nomor 13 Tahun 2006 tentang Pedoman Pengelolaan Keuangan Daerah. Kuncoro (2009:12) menjelaskan bahwa penelitian deskriptif meliputi pengumpulan data untuk diuji hipotesis atau menjawab pertanyaan mengenai status terakhir dari subjek penelitian.

\subsection{Tempat dan Waktu Penelitian}

Penelitian ini di lakukan pada Dinas Pendapatan Pengelolaan Keuangan dan Aset Daerah Kabupaten Minahasa Selatan dengan alamat Jl. Trans Sulawesi Kelurahan Pondang, Kecamatan Amurang Timur. Penelitian ini dimulai pada bulan Agustus - September 2016.

1. Mempelajari struktur organisasi dan job description Dinas Pendapatan Pengelolaan Keuangan dan Aset Daerah Kabupaten Minahasa Selatan.

2. Mengadakan Tanya jawab dengan manajemen / pejabat Pemerintah Dinas Pendapatan Pengelolaan Keuangan dan Aset Daerah Kabupaten Minahasa Selatan.

3. Mempelajari sistem dan prosedur penerimaan retribusi daerah Dinas Pendapatan Pengelolaan Keuangan dan Aset Daerah Kabupaten Minahasa Selatan.

4. Mengadakan perbandingan antara sistem dan prosedur penerimaan retribusi daerah yang diterapkan pada Dinas Pendapatan Pengelolaan Keuangan dan Aset Daerah Kabupaten Minahasa Selatan dengan Permendagri Nomor 13 Tahun 2006.

\subsection{Teknik Pengumpulan Data}

Teknik pengumpulan data yaitu penelitian langsung dilapangan. Pengumpulan data dilakukan dengan beberapa MetodeWawancara, yaitu pengumpulan data lewat tata muka dan melakukan tanya jawab secara langsung kepada pihak - pihak yang berkaitan dengan masalah yang diteliti dengan beberapa pertanyaan sebagai berikut :

1. Bagaimana gambaran umum dan struktur organisasi serta Job Describtion dari Dinas Pendapatan, Pengelolaan Keuangan dan Aset Daerah Kabupaten Minahasa Selatan?

2. Rertribusi apa saja yang ada dan diberlakukan di Kabupaten Minahasa Selatan?

3. Dokumen apa saja yang digunakan dalam penerimaan retribusi daerah Kabupaten Minahasa Selatan?

4. Bagaimana sistem dan prosedur penyetoran yang dilakukan oleh wajib retribusi?

\subsection{Metode Analisis}

Metode yang digunakan adalah metode analisis deskriptif yaitu metode yang digunakan untuk menguraikan, menggambarkan, membandingkan, dan menerangkan suatu data atau keadaan yang sedemikian rupa sehingga dapat memungkinkan untuk ditarik suatu kesimpulan yang sesuai dengan teori. 


\section{HASIL PENELITIAN DAN PEMBAHASAN}

\subsection{Deskriptif Objek Penelitian}

Dinas Pendapatan, Pengelolaan Keuangan dan Aset Daerah Kabupaten Minahasa Selatan dibentuk berdasarkan Peraturan Daerah Kabupaten Minahasa Selatan Nomor : 4 Tahun 2008 tentang Susunan Organisasi dan Tata Kerja Dinas Daerah Kabupaten Minahasa Selatan yang dijabarkan dalam Peraturan Bupati Minahasa Selatan Nomor : 21a Tahun 2008 tanggal 8 September 2008 tentang Penjabaran Tugas Pokok dan Fungsi Dinas Pendapatan, Pengelolaan Keuangan dan Aset Daerah Kabupaten Minahasa Selatan. Dinas Pendapatan, Pengelolaan Keuangan dan Aset Daerah Kabupaten Minahasa Selatan mempunyai tugas melaksanakan urusan pemerintahan daerah berdasarkan asas otonomi daerah dan tugas pembantuan di bidang Keuangan.Dalam melaksanakan tugas sebagaimana diatas, Dinas Pendapatan, Pengelolaan Keuangan dan Aset Daerah Kabupaten Minahasa Selatan mempunyai tugas :

1. Perumusan Kebijakan Teknis

2. Penyusunan, perencanaan, pengkoordinasian, pembinaan dan pengendalian pelaksanaan tugas.

3. Penyelenggaraan urusan pemerintahan dan pelayanan publik di bidang keuangan.

4. Pelaksanaan tugas lain yang diberikan oleh Bupati.

\subsection{Hasil Penelitian}

\section{Sistem dan Prosedur Penerimaan Retribusi Daerah}

Penerimaan pendapatan daerah dalam hal ini retribusi daerah Kabupaten Minahasa Selatan dapat dilakukan dengan 3 (tiga) cara, yaitu melalui :

\section{A. Bendahara Penerimaan}

1. Bendahara penerimaan menerima surat ketetapan retribusi daerah dari pimpinan (Kepala Dinas) selaku pengguna anggaran.

2. Menerima pembayaran retribusi sesuai dengan surat ketetapan retribusi daerah (SKRD) dari wajib retribusi.

3. Membuat surat tanda setor (STS) dan menyerahkan kepada wajib retribusi.

4. Melakukan penyetoran uang yang diterimanya kepada bank SulutGo beserta dengan surat tanda setor.

5. Menerima surat tanda setor yang telah diotorisasi oleh bank SulutGo dan membuat laporan pertanggungjawaban penerimaan retribusi daerah serta menyerahkan nota kredit dari bank SulutGo kepada Pejabat Pengelola Keuangan Daerah (PPKD) selaku BUD.

\section{B. Bendahara Penerimaan Pembantu}

1. Bendahara penerimaan menerima surat ketetapan retribusi daerah dari pengguna anggaran

2. Menerima pembayaran retribusi sesuai dengan surat ketetapan retribusi daerah (SKRD) dari wajib retribusi.

3. Membuat surat tanda setor (STS) dan menyerahkan kepada wajib retribusi.

4. Melakukan penyetoran uang yang diterimanya kepada bank SulutGo beserta dengan surat tanda setor.

5. Menyampaikan laporan pertanggungjawaban kepada bendahara penerimaan.

6. Bank SulutGo menyerahkan nota kredit kepada BUD atas surat tanda setor dari bendahara penerimaan pembantu.

\section{Bank yang ditunjuk oleh Pemerintah (Bank SulutGo)}

1. Bank menerima pembayaran dan penyetoran dari wajib retribusi dan SKPD yang melaksanakan pemungutan pendapatan daerah dalam hal ini retribusi daerah.

2. Setelah menerima pembayaran, maka bank menerbitkan dan menyerahkan bukti pembayaran dan nota kredit kepada wajib retribusi dan SPKD yang melaksanakan pemungutan pendapatan daerah. 
3. Setelah itu bank menyerahkan salinan bukti pembayaran dari wajib retribusi kepada bendahara penerimaan untuk dijadikan dokumen penerimaan bersama surat ketetapan retribusi daerah.

\subsection{Pembahasan}

\section{Analisis Sistem dan Prosedur Penerimaan Retribusi Daerah}

Sistem dan prosedur penerimaan kas digunakan untuk mencatat seluruh transaksi penerimaan kas. Berdasarkan Permendagri Nomor 13 Tahun 2006 mengatur tentang tata cara pengelolaan keuangan daerah termasuk di dalamnya dalam penerimaan retribusi daerah. Uraian diatas telah jelas menggambarkan tentang sistem dan prosedur penerimaan retribusi daerah oleh instansi yang menjadi objek penelitian, dimana ada beberapa jalur penerimaan yang dapat dilakukan sebagaimana diatur dalam Permendagri Nomor 13 Tahun 2006. Dari hasil penelitian yang dilakukan maka dapat kita lihat kesesuaian antara sistem dan prosedur penerimaan retribusi daerah yang diterapkan sebagai berikut:

\section{Tabel 1. Penerimaan Retribusi Lewat Bendahara Penerimaan}

\begin{tabular}{clc}
\hline No. & \multicolumn{1}{c}{ Prosedur Penerimaan } & Keterangan \\
\hline 1. & $\begin{array}{l}\text { Bendahara penerimaan menerima surat ketetapan retribusi daerah } \\
\text { dari Pimpinan (Kepala Dinas) selaku pengguna anggaran. }\end{array}$ & Sesuai \\
2. $\begin{array}{l}\text { Bendahara penerimaan menerima pembayaran retribusi sesuai } \\
\text { dengan surat ketetapan retribusi daerah (SKRD) dari wajib retribusi. }\end{array}$ & Sesuai \\
3. $\begin{array}{l}\text { Bendahara penerimaan membuat surat tanda setor (STS) dan } \\
\text { menyerahkan kepada wajib retribusi. }\end{array}$ & Sesuai \\
4. $\begin{array}{l}\text { Bendahara penerimaan melakukan penyetoran uang yang } \\
\text { diterimanya kepada bank SulutGo beserta dengan surat tanda setor. }\end{array}$ & Sesuai \\
5endahara penerimaan menerima surat tanda setor yang telah \\
$\begin{array}{l}\text { diotorisasi oleh bank SulutGo dan membuat laporan } \\
\text { pertanggungjawaban penerimaan retribusi daerah serta menyerahkan } \\
\text { nota kredit dari bank SulutGo kepada Pejabat Pengelola Keuangan }\end{array}$ & \\
Daerah (PPKD) selaku BUD. & \\
\hline
\end{tabular}

Sumber : Dinas Pendapatan, Pengelolaan Keuangan dan Aset Daerah Kabupaten Minahasa Selatan 2016

Tabel 2. Penerimaan Retribusi Lewat Bendahara Penerimaan Pembantu

\begin{tabular}{clc}
\hline No. & \multicolumn{1}{c}{ Prosedur Penerimaan } & Keterangan \\
\hline 1. & $\begin{array}{l}\text { Bendahara penerimaan pembantu menerima surat ketetapan retribusi } \\
\text { daerah dari pimpinan (Kepala Dinas) selaku pengguna anggaran. }\end{array}$ & Sesuai \\
2. & $\begin{array}{l}\text { Bendahara penerimaan pembantu menerima pembayaran retribusi } \\
\text { sesuai dengan surat ketetapan retribusi daerah (SKRD) dari wajib } \\
\text { retribusi. }\end{array}$ & Sesuai \\
3. $\begin{array}{l}\text { Bendahara penerimaan pembantu membuat surat tanda setor (STS) } \\
\text { dan menyerahkan kepada wajib retribusi. }\end{array}$ & Sesuai \\
4. $\begin{array}{l}\text { Bendahara penerimaan pembantu melakukan penyetoran uang yang } \\
\text { diterimanya kepada bank SulutGo beserta dengan surat tanda setor. }\end{array}$ & Sesuai \\
5. $\begin{array}{l}\text { Bendahara penerimaan pembantu menyampaikan laporan } \\
\text { pertanggungjawaban kepada bendahara penerimaan. }\end{array}$ & Sesuai \\
6. $\begin{array}{l}\text { Bank SulutGo menyerahkan nota kredit kepada BUD atas surat } \\
\text { tanda setor dari bendahara penerimaan pembantu. }\end{array}$ & Sesuai \\
\hline
\end{tabular}

Sumber : Dinas Pendapatan, Pengelolaan Keuangan dan Aset Daerah Kabupaten Minahasa Selatan 2016 
Tabel 3. Penerimaan Retribusi Bank yang ditunjuk Pemerintah (Bank SulutGo)

\begin{tabular}{clc}
\hline No. & \multicolumn{1}{c}{ Prosedur Penerimaan } & Keterangan \\
\hline 1. & Bank menerima pembayaran dan penyetoran dari wajib retribusi dan & Sesuai \\
& SKPD yang melaksanakan pemungutan pendapatan daerah dalam & \\
& hal ini retribusi daerah. & \\
2. & $\begin{array}{l}\text { Setelah menerima pembayaran, maka bank menerbitkan dan } \\
\text { menyerahkan bukti pembayaran dan nota kredit kepada wajib }\end{array}$ & Sesuai \\
& \\
retribusi dan SPKD yang melaksanakan pemungutan pendapatan & \\
daerah. & \\
3. Setelah itu bank menyerahkan salinan bukti pembayaran dari wajib \\
retribusi kepada bendahara penerimaan untuk dijadikan dokumen \\
penerimaan bersama surat ketetapan retribusi daerah.
\end{tabular}

Sumber : Dinas Pendapatan, Pengelolaan Keuangan dan Aset Daerah Kabupaten Minahasa Selatan 2016

\section{KESIMPULAN DAN SARAN}

\subsection{Kesimpulan}

Hasil Penelitian ini menggambarkan secara umum telah terbangun sistem dan prosedur yang baik dalam tata cara pelaksanaan penerimaan retribusi daerah baik itu melalui Bendahara Penerimaan, Bendahara Penerimaan Pembantu maupun Bank yang ditunjuk oleh Pemerintah Daerah untuk menerima pembayaran retribusi daerah ini yang merupakan bagian dari Pendapatan Asli Daerah (PAD). Hanya saja dalam pencatatan dalam setiap penerimaan masih kedapatan terjadinya kesalahan catat sehingga pada akhirnya harus dilakukan rekonsiliasi antara bukti penerimaan retribusi dari wajib retribusi maupun bukti penyetoran dari bank.

\subsection{Saran}

Saran yang dapat diberikan dari penelitian ini:

1. Pihak DPPKAAD Kabupaten Minahasa Selatan sebaiknya dapat mempertahankan sistem dan prosedur yang telah terbangun dengan baik dengan terus menjalin komunikasi yang positif dengan pemerintah daerah maupun swasta serta masyarakat dalam pelaksanaan penerimaan retribusi daerah yang merupakan bagian dari pendapatan asli daerah agar tercipta pendapatan pengelolaan keuangan dan aset yang transparan, akuntabel dan profesional dalam mewujudkan Minahasa Selatan yang Hebat dan Berdikari Cepat.

2. Untuk para pembaca kirannya hasil penelitian ini dapat menjadi referensi bagi peneliti selanjutnya agar peneliti selanjutnya dapat meneliti penerimaan retribusi daerah setiap tahun dan meneliti tentang sistem dan prosedur yang diterapkan sesuai dengan peraturan yang berlaku. Dan mampu meneliti setiap penerimaan yang menjadi bagian dalam pendapatan asli daerah, seperti pajak daerah dan lain - lain serta prosedur penerimaannya agar kita dapat memahami dengan benar dan bisa memberikan referensi yang baik kepada setiap pembaca, sehingga kedepannya akan menjadi perubahan kearah yang lebih baik. 


\section{DAFTAR PUSTAKA}

Ersita, M., ElimI. (2016). Analisis Efektivitas Penerimaan Retribusi Daerah dan Kontribusinya Terhadap Peningkatan Pendapatan Asli Daerah (PAD) di Provinsi Sulawesi Utara. Universitas Sam Ratulangi. Manado. Jurnal EMBA.4 (1) (2016) http://ejournal.unsrat.ac.id/index.php/emba/article/view/1936/1533. Diakses pada 10 November (2016) Hal. 889-897.

Janis, R.S., Sondakh J.J., Sabijono H. (2015). Analisis Sistem dan Prosedur Penerimaan PAD Pada Dinas Pendapatan Pengelolaan Keuangan dan Aset Daerah Kabupaten Sitaro. Universitas Sam Ratulangi. Manado. Jurnal EMBA.3 (1) (2015) http://ejournal.unsrat.ac.id/index.php/emba/article/view/1936/1533. Diakses pada 15 November (2016) Hal. 778-786.

Karamoy, Rone. (2013). Evaluasi Pelaksanaan Sistem Dan Prosedur Penerimaan Kas Pada Dinas Pendapatan Kota Manado. Universitas Sam Ratulangi. Manado. Jurnal EMBA. 1(3) (2013) http://ejournal.unsrat.ac.id/index.php/emba/article/view/1936/1533. Diakses pada 10 November 2016 Hal. 882-997.

Kuncoro (2009). Metode Riset Untuk Bisnis dan Ekonomi.Jakarta.Erlangga

Mahmudi, (2013). Akuntansi Sektor Publik. Cetakan Pertama. Yogyakarta.UII Press

Mardiasmo. (2018). Akuntansi Sektor Publik. Edisi Terbaru. Yogyakarta.Andi

Mardiasmo, (2011). Perpajakan, Yogyakarta. Andi

Moh. Mahsun, Firma Sulistiyowati, Heribertus Andre Purwanugraha, (2014). Akuntansi Sektor Publik. Edisi Ketiga. Yogyakarta.BPFE

Najoan, C., Sabijono H., Datu C. (2016). Analisis Sistem Pemungutan dan Penyetoran Retribusi Pasar Pada Dinas Perindustrian Perdagangan Koperasi dan Penanaman Modal Kota Kotamobagu.Jurnal EMBA.4 (1) Maret 2016 http://www.unsrat.ac.id diakses 7 Maret 2019, Hal 1107-1117

Pemerintah Republik Indonesia. 2006. Peraturan Menteri Dalam Negeri No. 13 Tahun (2006) tentang Pedoman Pengelolaan Keuangan Daerah. Jakarta.

Peraturan Pemerintah Republik Indonesia No. 24 Tahun (2005) tentang Standar Akuntansi Pemerintahan

Pemerintah Republik Indonesia. (2009). Undang - undang No. 28 Tahun (2009) tentang Pajak Daerah dan Retribusi Daerah. Jakarta.

Peraturan Pemerintah Nomor 71 Tahun (2010) tentang Standar Akuntansi Pemerintah

Peraturan Pemerintah Daerah Kabupaten Minahasa Selatan No. 4 Tahun (2012) tentang Retribusi Daerah. Minahasa Selatan

Taluke, Maxwel. (2013). Analisis Kontribusi Pajak Daerah dan Retribusi Daerah Pada Pendapatan Asli Daerah di Kabupaten Halmahera Barat.Jurnal EMBA1 (3) Desember (2013), http://www.unsrat.ac.id diakses 18 Februari (2019), Hal 385-393. 